to the earl of Antrim that inspired them with the courage requisite for the immediate undertsking. What the last messege was that Loord Dillon brought we do not know, only we may feel assured that it was not to conntermand the instructions sent by Digby. Whatever it Fas, it is excoedingly likely that it furnished Sir Phelim and Roger Maguire with the materisls for their forgery. If further proof of the forgery were necesagry, it might be gathered from internal evidence. For, as Mr. Gaxdiner points out (x. 92, n.), Charles would never have spoken of the presbyterians as protestants. One word more. It is commonly supposed that it ras only torards the close of Norember that the existence of the commisaion became known. But it is clear that it existed and was spoken about at the very beginning of the rebellion. There is sbundant evidence in the depositions printed by Miss Hickson to prove this; but whst puts it beyond a doubt is a proclamstion of the lords justices on 30 Oot. against the calumny of the rebels pretending to act by the ling's commission (Nalson, ii. 688).

R. DURLoP.

THE BATTIE OP BDGREMI.

Iv the January number of this Review Mr. T. Arnold, in a note on the battle of Edgehill, expresses a wish 'that some competent military man, scquainted with the tactics and means of attack and defence which were in faghion at the time of the Thitty Years' War, would take in hand the campaigns of our English Civil War, and give us accurate and rational acoounts of what was done.' As I have for some years, during time that could be spared from professionsl duties, been engaged on the task of collecting materials for a military history of the period in question, I venture to put before the readers of Mr. Arnold's note some of the conclusions I have formed regarding this particular action. Following Mr. Arrold's classificstion, I propose to examine, first, the sources of information available; and, secondly, the obscurities, contradictions, and omissions of the authorities.

I. Mr. Arnold ranges the sources of information under five heads, including contemporary accounts, either by eyewitnesses or by those deriving their information at first hand from such observers, and also those of more modern historians.

It appears to me preferable to consider only the statements mede by contemporaries. It is true that the statements of later friters deserve consideration whan based upon documents not previously arailable, or upon informstion specially acquired; but, judging from internal evidence, so much cannot be said of the accounts of the battle given by any of the four modern writers mentioned by Mr. Amold.

Taking, therefore, only the contemporary anthorities, it will be best to group them into two classes-Royalist and Parliamentarian-and to enter each authority in his own class in what appears to be the order of importance. For brevity's sake the names of the suthorities are given ahortly, and, to facilitate reference to the original documents, indications are also given, in the following lists, to the works in which they are to be 
found, and to the Catalogae of the British Musenm for IISS. or rare pamphlets.

\section{Boyalist Authoritice.}

1. Official decount. Thom. Coll E 126. 24, also in Rushworth.

2. Clarendon (History), book vi.

Clarendon, MS. of Life. Appendix to History, edit. 1849.

8. Bulstrode, Memoirs, 1721.

4. Account in Carte's Letters, rol. i.

5. Wertrick, Memoirs, 1701.

6. A Royalist in London, Harl MSS. 3783, fol 61, 62

7. Bernard Stuart, in Harl. IISS. 8788, fol 60.

8. C. H. in Hart MSS. 3788, fol. 68, also Ellis Orig. Letters, Ser. II. iii. 801.

9. Verney MSSS. (Hist. MSS. Commission).

Heath's Chronicle, 1676.

Sanderson, History of Charles I, 1658.

\section{Parliamontarian Authoritias.}

1. Offial Account (by six colonels), Thom Coll. E 124. 26, also in Rushworth.

2. Fiennes' Account, Thom. Coll E 126. 38.

B. Wharron's Account, Thom Coll. E 124. 32.

4. Ladlow, Memoirs, vol. i. 1698.

5. T. C.'s Account, Thom. Coll. E 128. 20.

6. J. B.'s Account, Thom. Coll. E 124. 33.

7. A Worthy Divine, Thom. Coll. E 124. 21.

8. Letter to Lord Mayor, Thom. Coll. E 124. 18.

9. Deserter's Repart (called by Mr. Arnold 'The Spy '), Thom. Coll. E 244.2

10. Special Passages, No. 12, Thom. Coll E 126. 1.

11. Special Passages, No. 18, Thom. Coll. E 126. 26.

12. Gentleman of Quality, Thom Coll. E 124. 12.

18. Captain Keightley's Account, Thom. Coll. E 126. 18.

14. Hollio, Memoirs, 1699 (Maseres tracts).

15. Various, in news from Orford, Thom Coll. E 127. 6.

Viears (God in Moont).

May (Parliamentary History).

Whitelocke (Memorials).

Rushworth (Collections).

Spalding (History of the troubleg in reign of Chartes I.).

Baillie (Letters).

In these lists the sathorities, whose acconnts are evidently based, in more or less degree, on the statements of some others in the lists, have not been distinguished by a number. They all, however, were in the position of getting information at first hand, and occasionally record facts or opinions which are asefol to the stadent.

By comparing these lists with those given by Mr. Arnold, it will be seen that an addition of some eight anthorities has been made, of which number the royalist accounts, in Carte's Letters, and in the Harl. MSB. are of considerable importance. The Deserter's Report is very valusble for its statements regarding the composition of the king's army, and for the positive estimate it gives of the loss of the royalists at the battle. In the matter of the relative importance of the suthorities $1 \mathrm{am}$ in accord with Mr. Arnold, except in the case of Bulstrode. Bulstrode was a soldier, had been ander fire before, and, from the internal evidence of his 
account, separate statements of which are corroborated by other authorities, appears to have carefully observed and clearly remembered the first stages of the action. As he was one who pursued to Kineton, be cannot be expected to detail what occurred during his absence from the field, and he is candid enough to point out thst, in the 'burry and smoke' of a ' set field,' it is only natural that a 'man takes notice of nothing but what relstes to his own safety.' As some further evidence of his shrewd and impartial judgment, it may be noted that he expressly states, with reference to the result of the action, 'I think we had no great reason to brag of a victory.' No other royalist writer makes, with reference to the general result of the day, so candid an admission.

III In disoussing the obscurities, contradictions, and amissions of the authorities, Mr. Arnold notices three points which are uncertain, viz. the action of the royalist left wing, the disposition of the parliamentary centre, and the position, in battle order, of the cavalry regiment belonging to the prince of Wales. The last of these is evidently, however, a minor point, when compared with the first two uncertainties. But other diffculties not mentioned by $\mathrm{Mr}$. Arnold erist, such as the numbers of the opposing forces ; the exsct method adopted by each party of marshalling its forces; the position and manner of employment of the artillery; the various tactical changes during the course of the fight, and the loss on ach side. I purpose to consider of these-

(a) The number and constitution of the troops engaged on each side.

(b) Their disposition when drawn up in battle order.

(c) The main features of the combat.

(a) In a pamphlet in the Thomsson Collection (E 83.9), and reprinted in Mr. Pescock's army lists, will be found the first published lists of the forces of the king and of the parliament. Thomason himself notes, in manuscript, the date of the publication of this pamphlet (December 1642), which fact would appear to dispose of Mr. Pescock's contention that these lists were not published till after $1 \mathrm{Jan}$. 1649. Whether or not we may fairly accept the ling's list as representing the army engaged at Edgehill, there is no question thst the parliamentary regiments at Edgehill are all to bo found in the pamphlet, as weil as in a separate list of the army raised under Esser (E 117. 3), of earlier date. So that the lists of both royal and porliamentary armies may fairly be assumed as representing, on the whole, the forces employed at Edgehill, doe allowences being made for the absence of certain regiments on detached duty. At this stage of the inquiry the Deserter's Report is of singular interest and great importance.

The king's 'marching army' is stated in the pamphlet to consist of fourteen regiments of foot, esch consisting of sbout one thoussnd men, and some one thousand five hundred caralry. We know, however, from Clarendon and others that, by the time the king advanced on London from the borders of Wales, the cavalry had been, by the efforts of Bupert, much improved and increased in numbers. According to Clarendon, the army of the king, within three weeks of coming to Shrewsbary, amounted to sir thousand foot, two thousand horse, and one thousand dragoons, the foot being divided into three brigades. Confirmation of this statement occurs in a pamphlet, ' A Remonstrance of the Present State of the Kings Armie ... 12 Oct. 1642' (E 121. 86), which states that a general 
muster of the royal army was attended by 6,800 foot and 1,950 horso. The Deserter's Account, written after Rdghill', agrees ramarbably with the army list. He gives fifteen regiments of foot, six regiments (forty troops, some very wreak) of horse, and forr regiments of dragoons; and twelve of these infantry regiments, mentioned by him, are to be found in the army list. As he also gives the names of the colonels who commanded four regiments that were out to pieces at Edgahill, we obtain, by comparing his statements with the list of regiments in the army list, a tolersbly socurate method of compating the royaliat force engaged at Edgehill, though not 80 certainly as to give the actual names of all the regiments.

In the case of the other army the matter is more clear. We can, by compering the army list with the various independent gtatements made by the different anthorities, not only arrive at a very fair estimate of the numbers engaged, but at a probsbility, which is almost certainty, of the actual distribation of this foree on the fleld.

As regards the royalist army at Edgehill, the following statements are made :-

Offioinl Acoount (Partiamentary). Most of harse on right wing. Loft wing anly ten troope. The foot 'sppeared to us divided into nine great bodies.' King's forees larger than expeeted, and extimsted by somo at 18,000, by others st 14,000.

Fiennes mentions a similar dipposition of the harwe, adding that there wore dragoone also on the left wing.

T. C. entimates the army at 84,000 -an evident exesperation.

Captain Keightley angs fiftoen regimants of footh and sixty regiments (ho means troops) of haree.

Bolntrode gives no detail of numbers, but montions that drapoons were on both flentre, and that the reserve consisted of 600 horse onder Carnsrron.

Bermerd Btourt stetes that the ling bed 12,000 foot before the battla.

The Deserter anys the hing Iost 2,000 billod or dirpersed.

The conclusions drawn trom a careful study of all the authorities bearing on this point aro-That the total royalist forco at Edgahill amounted to 18,000 or 14,000 men, of which 9,000 or 10,000 were infantry, and 4,000 were horse and dragoons. There was, besides, a amall train of artillery.

The parliamentary forces mey be estimated with grester cartainty. The army list, already quoted, gives 20 regiments of foot, esch nominally 1,200 men; 75 troops of horse, each troop consisting of 60 men; 5 troops of dragoons, each 100 strong; besides certain specisl troops, such ss 3 companies of firelocks, 100 cuirassiers, 50 carbines (these two forming Essex's lifoguard), and a train of artillery. The 76 troops of horse wore, apparently, ' regimented ' under six colonels.

$\Delta$ list of the regiments-which are always distingwished in the various socounts by the names of their colonals-is of grest importance in deciding the actoal details of the combat and the position of the troops.

Names of the Colonols commanding Reginonts in the Parliamontary Arwy.

Bayd of Eeser.

Sir John Mfoyrick. (Left at Worcestar.)

Earl of Potorborough (In Benbury.) 
Barl of Stamfond. (At Heroford.)

Iord Bay.

Iord Wherton.

Lord Roohford. (At Coventry. Ceme up on Mondeg.)

Lord St. Jokn. (Worcester.)

Iord Brook.

Iord Manderile.

Iond Boberte.

Colonel Chalmiloy.

Colonal Hallie.

Colonol Basnfold. (? 'Bartham' of The Worthy Divine. May have been in

Banbury. Whitlook seys two regiment in Banbury.)

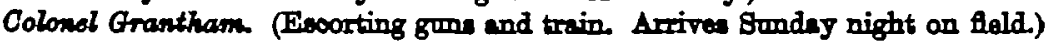

Bir Win. Conrtable.

Colonel Ballard.

Sir Wm. Fairfar.

Colonel Charies Essed.

Oolond Bampdom (EBoorting train. Arrives Sundey night).

In this list the regiments belonging to the officers whose names are printed in italics were, according to different parlismentary anthorities, not at Edgabill, being on detached duty as entered opposite to the name of each concerned. The rest are exactly twelve in number, and sill of them are mentioned as being at Edgehill.

As regards the parliamentary army at Edgehill, the following statements are made by the suthorities :-

Official accoont (parlismentary) definitely states that at Edgehill thare wore eloven regiments of foot, forty-two troops of horse, and seven humired dragoons.

Fiennes has an extro infintry regiment, and makes no mention of dragoons.

Wherton agrees generally with the offleial socount, though ho urderstates the cavaliry.

T. C. bes thirteen regiments foot, thirty-eight troops horse, and one thousand dragoons.

The Worthy Divine hes twalve regiments foot, fifty troops haree, and two regiments dragoons. As this writer was one who passed from rank to rank, exhorting the troops to the fight, bis statement, when it differs from the ofloirl eccount, deserves to be carefally weighed. Vicars (God in Mount), it may be remarted, states there Fere eleven or twelve regiments of foot prosent.

Cepptain Keightloy's egtimate is very similar to the offoial ac00unt.

Clarendon (History), stating that the parlismontery forees woro experior to the royalins, mentions that their right wing consisted of two regiments (i.a. ton or twalve troops) of harse, and the left of one thousend harse. There wis also, ho seys, a 'good resorve' of harse.

Taking the actual regiments mentioned by name in the rarious authorities, we find that there must have been on the ground 18 regiments of foot, 48 troops of horse, and 700 to 1,000 dragoons; and, allowing for incomplete numbers, that Essex must have commanded in the field - force amounting to 11,000 infantry and 8,000 horse and dragoons. While superior, therafore, to the ling in infantry, he was weaker in cavalry; and, taking into consideration the greater relative importance of cavalry in those days, as well as the superior quality of the ling's horse, it may 
be assumed that, while the two armies were numerically about equal, the prepanderance of strength was on the side of the royalists.

(b) My investigations incline me to differ considerably from the conclusions arrived at by former writers regarding the ranging of the opposing armies in battle order. In studying a matter so technical as this is, it is essential, as Mr. Arnold points out, that the erolutions and tactics employed at the time should be cleariy understood.

The methods of Farfare in use daring the civil war were animated with the spirit, and directly based on the practice, of the two great captains of the ago-Marrice of Nassan and Gustarus Adolphus. A very large number of the officers employed on both sides had served their spprenticeships under one or other of these lesders. It is interesting to note that Clarendon himself (History), in referring to the very battle we are now considering, states that Bapert had drawn a 'figure' for the marshalling of the royel army (note that Lloyd in his 'Mémoires' states that Rathren marshalled the royel army), while Iindsey, the commander-in-chief, 'preferg ' another 'figure' drapn up in accordance with the methods practised onder the Nassan princes, under whom both be and Essex had held commands. It will shortly be shown that the formations respectivaly adopted by the royalists and parliamentarians at Edgahill were essentially different in principlo-that of Essex being in accordsnce with the custom of the Netherland princes, while that of the royalists was somewhat exceptional. May we not surmise, there. fore, that one of the grounds of Lindsey's resignation of the general direction of the action was dissatisfaction with the judgment of the king in favour of the 'figure' proposed or advocated by Rupert; that it was on this 'figure' that the royalists were ranged; and that it was in part due to these new evolutions that the king at Edgehill failed to secure the victory so confidently expected by his officers at the opening of the fight?

In drawing up troops of all arms 'in battalia,' as the term used at the time wo-a term which Mr. Sanford somewhat incorrectly translates (p. 520) by 'setting themselves in battalion'-the usual custom was to have, in first line, a certain number of infantry 'tertia,' or regiments, in the centre, and to 'wing,' or flank, these with horse and dragoons. Sometimes the intervals between these bodies were very gmall-not more than twenty-five yards; but in ordinary circumstances it was generally considered the better practice to allow intervals between the bodies at least equal to the frontage occupied by one of them. About 100 or 150 jards in rear of the first line, a second line, arranged similarly to the first line, was drawn up, the only difference being that the regiments of the second line froed the intervals of the first line, with the object of avoiding the disastrous confusion that would inevitably occur were the first line broken and forced back on the second. Occasionslly a third line supported the second; the depth between the second and third lines being, however, frice as great as that between the first and second. The proportion of cavalry in such a third line was usually grester than in either of the other two lines. It is well lnown that the beyonet, although invented about 1640, had not at this time come into general use anywhere, and certainly not in England, as in Sir James Turner's military 
essays (1683) the pike is mentioned as still being in ase, and this weapon continued to be the regular 'white arm' of the infantry till quite the end of the serenteenth century. In the 'Gentleman's Dictionary' (1708) it is alloded to as having only lately become obsolete. The infantry 'tartis" rere, in consequence, composed of musketeers and pikemen in varying proportions. About the time of the civil war the masketeers were never less in number, and usually somewhat more numerous, than the pikemen. These latter occupied the centre of the regiment in parade formations and field evolutions, the whole body being drawn up ten, eight, or six deep in file, the last number being, very soon after the commencement of the war, almost universally adopted. The cavalry were drawn up similarly, either by troops, or by regiments composed of several troops. The troop comprised certain officers, trumpeters, and fifty or sixty sabres. The ordinary cavalry were armed with the sword and a 'case' of pistols. Inancers were rarely employed during the war, but heavily armed cuirassiers were much thought of, and frequently employed. Cavalry bodies were; in most cases, drawn up three deep. Dragoons, at the time, were essentially mounted infantry; and in these modern days, when the use of such a body of troops is being revived, it is of interest to note the various duties on which they used to be employed during the civil wars. In a general action they were frequently mixed with caralry, or ased to occupy posts on the flanks of the line. Infantry, usually ' commanded' (i.e. selected) masketeers, were often 'lined' (or mixed) in small bodies with the caralry, with the object of breaking by their fire the charge of the opposing cevalry. This plan, it has been supposed, was the invention of Gustarus Adolphus, but, as a fact, it is older, having been employed in France nearly a century earlier than the time of Grastarus. Sometimes lines of battle were drawn up by intermingling the caralry and infantry, bat the more general plan was as has been described.

The artillery was at this time very deficient in mobility. Its practice also appears to have been very uncertain, and usually very bad. But no donbt its moral effect, especially against cavalry, was considerable. In battle order it was usually drawn ont in front of the line towards the flanks; it also was used, when large intervals separated the units of the first line, to occupy those intervals. The germ of a light field gun already existed-the 'lesther pieces' so frequently mentioned in contemporary accounts-and such lighter pieces were beginning to bo employed as battalion guns. The leather guns, it may be stated, consisted of a light copper or brass tube surrounded with hempen cord, which again was covered with leather; examples of such gans are still to be seen in musenms in England and elsewhere.

At the battle of Edgehill almost every one of the technical points allnded to was illustrated by the practice of either the royalists or their opponents. If anyone should wish to study this part of the subject more in detail, perbaps the work of Sir James Turner ('Pallas Armats," 1683 ) is the best authority. He is clearer, and more definite in statoment, than most of his contemporaries, and in Chapter XVII., 'On Embattelling,' while stating the more modern practice in use when he wrote, he constantly makes references to the older methods.

Before discussing the actual bettle orders at Edgehill, it msy be as well 
to mention that regiments then, as now, were urually brigaded ander the command of a general officer, or a colonel. The brigades consisted uscally of three or four regiments, and as in marching order the whole army wis divided into three bodies, called respectively the 'van' the ' battle,' and the 'rear,' it follows that at Edgehill, where the infantry of both sides consisted, in each case, of three brigades, each of these brigades would naturally be called the van, battle, or rear, according to the order of march sdopted on that particular day. The importance of this consideration will be evident a little forther on.

As regards the marshelling of the army of the parliament, the following statements are made by our anthorities :

Parliamentary official sccount. Right wing horse three regimenta, vir. Essox's regiment commanded by Stspletom, Balfowr's regiment, and Fielding's regiment.

Next theoe, the foot in three brigades:

18t. The 'van'-Meldrum.

2nd. The ' middle'-Colonel Chase. Eswex.

8nd. 'In the rear'-Colonel Ballard's brigade. This consinted of the regiments of Lord Essex, Colonel Bellard, Iord Brook, and Colonel Holli.

In the latt ping twenty-four troops commended by Sir James Ramsay.

Fiannes agrees entirely with the official account, notwithstanding that ho, by a slip of the pen, or of memory, curionsly transposes the words 'right ' and ' left' Ho adds that the foot was 'a good space' behind the horse 'when we began to charge.' It is to be remembered that he personally was in Balfour's regiment of horse on the right wing. Ho slso itates a frot which, on eccornt of his position on the fleld, he had the best means of knowing, vir thet Fielding's cevalry regiment was behind the other two regiments and in second line.

The lord mayor's correspondent (No. 8 pardismentery wothority) the wings of covalry were flented with dragoons.

T. C. States that the loft ring (of foot) consisted of flve regiments (Wharton, Mandovile, Cholmloy, Calonal Fesex, and Fairfax), that of Fairfax being in the rear.

The right wing (of foot) consisted of the 'land general's' regiment (i.e. Ereas's), and comprised Escex's own foot regiment, and those of Brook, Roberts, Hollio, and Meldram. (Meldrum was colonel of Lard Bey's regiment at Edgahill ; wee J. B.'a statement.)

Offecial royalist socount. On left flents of enemy a hodge fras ocoupied by muaketeris.

Bulgtrode. Fnomy hed entrenched their gank. Their horse were 'lined ' with foot on loft wing, and speced at intervals for entranos of reservo of harse. On enemy's right were some 'briars' ' pocupied by dragoons

Three guns from left ping of enemy fire on royulist advaneing carahry.

Bernard 8tuart gay" guns were 'lined' among the partismentary horse, thus corrobarating Bulstrode.

Iondon royalist angs 'Left wing' of enemy consisted of three rogiments of foot and the grenter part of their harse.

Clarendon (History) seys thero were hedges on right of enomy's bine, occupied by monkcteers; that on this Alsnt were two regiment of horse, while on left flank thare was one thonasand horse under Sir James Ramsay. The ' reserve' of hose wes a ' good' ane.

Taking all these statements together, and with proper allowance for 
relative weight, it seams diffoult to avoid drswing the following conelagions :-

At Edgehill, Essex's battle order was in two lines, esch line consisting in the centre of infantry regiments, drswn up, probsbly at foll intervals, with cavalry on brith flanks.

The first line, commencing from its own right, consisted of the following detail :-

1. Dragoons oceupying enclosed and broken grownd.

2. Cavahy regiment ander Stopleton.

8. Cevalry regiment under Belfour.

4. Roberts $\left.\begin{array}{l}\text { Constable } \\ \text { Bey (Meldrum) }\end{array}\right\}$ 1et infantry brigado under Maldrum-the ' ven.'

6. Esesex (Colonel Charies)

Wharton

Manderilo

Cholmley

Ind infantry brigado under Colonal Ewar-

6. Intt wing of harse, consirting of a portion of twenty-forr troops, probably 'regimented' into three or four regimente, and commanded by Bir James Ramas. This cevalry was 'lined ' with selootod musketoers of Ballard's and Hollis's regimente.

7. Dragoons and mosketears cocupying enclosed and broken ground.

The second line, commencing enameration from the right, was as follows :

1. Fielding's cavaby regiment.

2. Iord Eesex's regiment

Lord Brook's regiment

Ballard's regiment

Hollis's regiment

Fairfax's regiment

The fint fow regiments mentioned forming Ballard's brigade, and Fairfax's regiment form. ing part of Colonel Chartes Eseser's brigade.

8. Cavaly. Bame of the twenty-four troops commanded by Barasay. As the action commenced it is probable that the carahy of the second line, on this left flant, gradually reinforeed the first line with the object of preventing outflankment by the superior numbers of the royal cavalry ander Bupert.

For every detail given above anthority can be cited; more space than is here arailable wovld, however, be required, if we were to examine fully the grounds and argoments for each statament.

The artillery pras probably placed in front of the first line, towards the flanks, and in the intervals between the regiments. In the cases of both infantry and cavalry the bodies were originally drawn ap at good interrals; probsbly on the left ping, as the possibility of being outflanked by the royalist cavalry declared itself, the first line ras gradually artended towrerds the threstened flenk, by bringing ap the regiments of the second line of cavely to reinforce the first line.

The details of the distribation of the royalist forces cannot be determined with equal probsbility. The anthorities give us, however, some indications of the formation adopted by the hing's marshal :-

Official royelist sccomt says that there ware dragoons on the loft wing.

Clarendon says the infantry consisted of three brigedes, respectively com. manded by Sir N. Bgron, Colonel Wentworth, and Calonal Fialding. The 
ling's grards and Lindsay's regiment stood nert each other in the line of battle. The greater part of the dragoons were on the left wing, the cavalry here being ondor Wilmot. Iord Byron commanded a reservo of horse consisting only of his own regiment. As the result of the uction, only one brigade of foot was broken and thrown into disorder.

Bulstrode states that the whole army was in one 'body,' the horse being on the wings. The horse were drawn up three deep, the foot sir deep. The caralry regiment of the prince of Wales (in which he himself rode) was in the right ring, which was flanked by dragoons under Washington. The other flank was covered by a regiment of dragoons under Lisle and Ennis. Thare was, he seys, a reserve of six hundred horse under Carnarvon.

Warwick, however, states that there were two bodies of reserve cavalry commended, the one by Digby, the other by Byron.

Offeial parliamentary account says that the royal foot were 'divided into nine grest bodies,' and that these 'crme ap all in front.' The horse and dragoons amounted in all to four thousend, of which number only ten troops of horse were on the left wing. By implication we can gather that the extreme left of the royalist foot was occupied by the ling's guards and Lindsay's regiment. At the close of the action two regiments of the king's foot retired in an orderly manner, and made a stand on some gans protected either by an entrenchmont or by a nataral ditch.

The Deserter mentions that four regiments were practically annihilated at the battle, and that the regiment of Sir L. Dives also suffered mach loss.

Taking these statements one with another, the most that can be said regarding the disposition of the royal army is that the battle order consisted of a single line of nine regiments of infantry, flanked, as usual, by caraly, the greater portion of which-i.e. about fifteen hundred horsowere in the right wing under the command of Bnpert. The brigade originslly detsiled for the reduction of Banbury is stated to have been that commanded by Sir N. Byron, and its force is said (official acconnt) to have been 4,000 men. As the Deserter says the regiment of guards contained 1,500 men (the parlismentary anthorities also testifying to its strength), and as it is probable that Lindsay's regiment was also a strong one, it is a reasonable assumption to suppose that the brigade of Sir N. Byron included these regiments and occupied the left of the infantry line. Beyond this nothing definite can be asserted as regards the disposition of the infantry. The dragoons were emplojed on both flanks, and there seems to have been a amall reserve body of cavalry on each wing, Camarron (or Digby) in command of that on the left, in all some six hundred sabres, and Byron in command of that on the right, con. sisting in all of some four hundred sabres. This position is given to Byron's command, as Clarendon says that the reserve, which he also states was commanded by Byron, joined in the parsuit of the parlia. mentary caralry when broken by Bupert's charge. The royal artillery was probably disposed in a manner similar to that adopted by the parlis. ment, though it is most likely that several gons were massed at a spot which gave them protection and possibly a command of fire; for the retreating infantry, it is stated, fell back on some such position.

(c) In considering the main festures of the actual combat, the theories, relating to the marshalling of the forces, which are now advenced, fit in very well with the statements made by the different authorities. The action is commenced by artillery fire, which is, comparatively speaking, 
harmless; the parliamentary left wing is outflanked by Rupert, and after the dragoons on both wings have cleared the hedges and enclosures the great cavalry attack takes place. Rupert's charge is perfectly successful, and the broken and disorganised enemy are thrown back on the flank of the infantry line, and, in the main, on the flank regiments of the second line. At the same time, the infantry of the left in first line are taken by panic and, breaking away, add to the confusion of the rout; the pursuit to Kineton takes place. Meanwhile Wilmot, on the left wing, has been gaining ground to the front as well as to the flank, and finally charges, and routs, Fielding's regiment standing in second line; Stapleton's and Balfour's regiments are missed altogether, having probably advanced forwards and inwards towards the centre of the line, to meet and desl with the royalist infantry of the leff. Owing to the absence of the cavalry, the reserves even having joined in the hesdlong pursuit, this infantry is at last destroyed by the combined exertions of cavalry and infantry, and the remaining regiments of the king's army sallenly fall back on their gans. At this juncture the royalist caralry begins to return in broken order, having boen checked in the pursuit by the approsch of the parliamentary force escorting the train. It is yet possible to retrieve the day, but the rain of their infantry makes these ill-disciplined cavaliers very unwilling to undertake any forther effort, and the battle comes to a standstill. As Clarendon says, "the hope of so glorious a day was quite vanished;' and the two armies, or rather the remnants of them, stand in the twilight of the waning day, ancertainly watching each other, till 'night, the common friend to wesry'd and dismay'd armies,' parts them. And so ends the first of those drawn battles, of which there are 80 many instances in the history of the civil war.

The battle of Edgehill is a remarkable illastration of the force of the military maxim, the utterance of which is often attributed to some grest modern leader, but which, if not stated at some still earlier period by some more ancient tactician, is to be found in the 'Art of War' of Roger earl of Orrery (1677), where it is laid down that "whoever has the last reserves is very likely at last to be the victorious.' W. G. Ross.

TEE ASSASBINATION OF GUSTAVUB III OF SWEDEN.

Trir assassination of Gustavus III (16 March 1792), at the very moment when that adventurous prince was sbout to lead the first coslition against revolutionary France, Fas an event of European importance. It is not, however, with the consequences of the catastrophe, bat with the catastrophe itself, that we now propose to briefly deal, for documents hspe only recently come to light which make it necessary to completely rewrite the history of the fatal masquerade at which the 'roysl charmer' lost his life. Sierakowski's circumstantial description ${ }^{1}$ of the murder, which has hitherto been the authorised version, and of which the numerous French versions are only so many copies, may now be regarded as apocryphal. As

1 Eistoire de l'assassinat de Gustave III. . . Par un officinr polonais [Court Sierekoroski] tomoin oculaire. Paris, 1797. 